\title{
Renina Katz e sua arte
}

\author{
Radhá A Bramo entrevista Renina KatZ
}

$\mathrm{N}$

A VIDA cultural no Brasil há uma área em que as mulheres não estão em desvantagem frente aos homens - nas artes plásticas. B asta acompanhar o noticiário da imprensa para se constatar essa realidade. Todavia, como a atividade dos artistas plásticos - mulheres e homens - normalmente é solitária, cada um em seu ateliê, sua trajetória particular é pouco conhecida do grande público.

Sendo assim, ESTU D OS A VA N Ç A D os procurou uma destacada artista plástica, Renina Katz, a fim de registrar as particularidades desse métier, quais sejam, a xilogravura, a pintura, a litografia e a gravura em metal, além de sua atuação no magistério. Para tanto, recorremos à colaboração, como entrevistadora, de Radhá Abramo, conceituada crítica de arte que há várias décadas vem acompanhando os trabalhos de R enina, sempre marcados pela qualidade apurada e pela busca de novos caminhos.

$\mathrm{N}$ a entrevista, realizada em 7 de agosto, além de fornecer importantes dados a respeito de características singulares de seu trabalho, R enina faz uma síntese sobre a trajetória da gravura no Brasil, destacando a contribuição de muitos daqueles que balizam a história das artes em nosso país. (M arco A ntônio C oel ho)

R adhá A bramo - Renina, eu a conheço há muitos anos. Acompanho seu trabalho porque você procura renovar e redescobrir um meio de representar a criação sempre de um modo profundo e diferente. Faz isso por meio da técnica, da tecnologia artística, que criou para seu trabalho. Ele é muito especial porque, em primeiro lugar, tem uma maneira de ser particularmente interessante. É como se fosse um vir a ser. É próprio da gravura esse sentimento do ser, do como será, porque na gravura, quando se faz o trabalho, não se sabe o que vai sair.

I magina-se o que pode resultar e qual técnica deverá ser empregada para fazer esse trabalho com leveza. M as, o grande mistério da gravura é exatamente esse. É romântico porque tem uma técnica supertrabalhada e enraizada: na cor, no buril, na chapa. Ela tem de mostrar exatamente aquilo que o artista está pensando que vai produzir. Então, é um vir a ser. Essa questão de ser, de uma forma, vamos dizer, imponderável, é a tecnologia, a maneira como se trabalha, que, aos poucos vai qualificando mais, fornecendo alguma segurança para se saber, a priori o que vai se fazer. M as o objeto produzido, depois de trabalhado, é exatamente aquilo que se conseguiu fazer. É uma relação da artista gravadora com o vir a ser, e com um certo romantismo, que é muito importante. Roman- 
tismo no bom sentido. É importante porque ao se ter uma tecnologia extremamente caudalosa, correta, certa, é impossível não existir uma para a realização desse tipo de trabalho. C aso contrário a gravura ficaria amarrada e talvez até fria, como sucede com alguns artistas que acabam presos dentro de uma frigidez. Você não, você faz tudo isso de forma diferente.

$\mathrm{N}$ unca disse isso a você e estou dizendo agora. É preciso ser romântico. $M$ as não no sentido, vamos dizer, do século XIX, e sim no sentido atual, que se dá o direito de sonhar. 0 direito de fazer formas diferenciadas, esse direito de voar, de ir para o espaço, é o que você faz com sua gravura.

R enina Katz - Radhá, você tocou em um ponto curioso, o do vir a ser. Em qualquer atividade é assim, mesmo na ciência. Você tem uma hipótese e trabalha sobre ela. De repente, durante o processo, alguns acasos ocorrem e criam novas possibilidades. Com a criação artística não é diferente. Com o gravador, especialmente, há um dado que faz a diferença, pois nos artistas o pensamento é visual. Eles não têm o pensamento verbal como expressão para o seu trabalho. Eles não pensam a cor vermelha pela palavra, pensam-na como uma sensação luminosa. O s gravadores têm de pensar não só na construção do trabaIho, na sua organização formal, mas devem saber que aquilo sairá ao contrário. Ao imprimir, o que está na esquerda sairá à direita. Esse é um conhecimento mínimo e básico, que deve estar na cabeça do artista, porque isso é que faz a diferença na gravura. Por isso os pintores, quando queriam saber se um trabal ho estava bem equilibrado, o colocavam diante de um espelho, pois a inversão apontava quais poderiam ser os desequilíbrios.

$\mathrm{N}$ a gravura, a técnica é fundamental, tal como é na pintura ou na gramática, para o escritor e o poeta. $\mathrm{Na}$ gravura tem-se um dado a mais, que é um complicador, visto que em algumas modalidades de gravura não há retorno. Se você erra, precisa jogar fora e fazer de novo; na pintura raspa-se e pode se aproveitar 0 suporte, refazendo o trabalho. M as na gravura é quase impossível, é um erro letal. Às vezes, consegue-se incorporar alguns erros, mas quando estes são erros de natureza técnica, que irão prejudicar a clareza da imagem ou até mesmo o projeto artístico, aí não tem jeito, tem de refazer. Para isso, deve-se ter o domínio técnico, criar uma espécie de disciplina, não férrea, pois o gravador não é um soldado. M as é necessário ter domínio técnico, o qual está baseado na disciplina.

\section{A liberdade de criação e o domínio técnico}

Eu costumava dizer aos meus alunos que a disciplina não é necessariamente uma prisão. Ao contrário, ela libera. Você precisa conhecer para ser livre. Q uem não conhece, acerta por acaso. Para ser livre, o conhecimento é fundamental. Para se ter a liberdade de criação, é necessário o domínio técnico, que está apoiado, evidentemente, numa disciplina que vai orientar a conquista dos meios.

Gosto da gravura um pouco por causa disso. Ela é um permanente desafio, sempre propõe um aperfeiçoamento nesse desafio. O briga a essa coisa a que se 
chama perseguição. $\mathrm{N}$ ão a da perfeição, mas a do máximo que se pode dar com qualidade. É difícil encontrar uma gravura frívola. A gravura dificilmente é decorativa no mau sentido. Ela não nasceu exatamente para ser um objeto de decoração, nasceu com outros propósitos, entre outros o da divulgação. E nfim, historicamente, sabe-se que na I dade M édia ela servia, por meio de suas imagens, para a difusão de doutrinas. $\mathrm{N}$ a sua origem há um compromisso com a multiplicação. I sso também agrada-me muito. $\mathrm{N}$ ão que a multiplicação seja democrática tão somente etc. Ela tem história de ser veículo, de abertura, de aperfeiçoamento das pessoas. Cria uma espécie de educação do olhar também. Enfim, faz com que alguém chegue a todo mundo de uma maneira igual. D emocrático ou não, não é o importante. A gravura tem na sua origem, na sua história, esse dado generoso, que também me agrada muito, que é o de evitar a escassez. Existem porém gravuras, digamos decorativas, principalmente as feitas em silk-screen, que têm essa função. Eu, pessoalmente, gosto menos do silk-scren.

\section{O imprevisível na gravura}

R adhá - A gravura, vamos chamar, "mais primitiva", é mais saborosa...

R enina - É a gravura mesma, porque ela envolve o ato de gravar, o sulco, o movimento da mão e o conhecimento, que implicam processos químicos. Tudo isso obriga a um tipo de pensamento que é muito particular. I sso não quer dizer que na gravura não se conte com os acasos, como um dado enriquecedor, como em qualquer processo. Eu chamo de acaso. De repente, acontece uma coisa que não é exatamente um acidente, porque não chega a prejudicar a imagem. M as, por conta do imprevisível, ocorre alguma coisa que é muito boa também quando bem incorporada.

São os mistérios, não só da arte, mas da vida, e se percebe que aquele acaso criou uma oportunidade para se rever o projeto original. A gravura, portanto, tem esse lado. Tem-se o projeto básico na cabeça e passa-se para um esboço, se for o caso. D epois, existe o desenvolvimento, esse cuidado, essa aproximação. É uma relação de intimidade. 0 uso adequado da técnica para isso é fundamental. $E$, se não se domina o meio, não se faz nada. Se você tem um pincel e uma tinta ainda pode arriscar, mas na gravura é diferente. D eve-se saber que o riscado à esquerda sai à direita, que tipo de ácido é melhor para isso ou aquilo, que um sulco errado não volta etc.

Enfim, os procedimentos devem fazer parte do cotidiano, do trabalho. Por meio disso conquista-se e inova-se al gumas coisas no trabal ho, através do tempo. Por que algo é feito assim e não de outra maneira? E se eu fizer assim? H á esse diálogo...

\section{A fase da xilogravura}

R adhá - H ouve uma mudança natural na imagem que você sempre usou para seu trabalho. Lembro-me daquelas figuras que você fazia com tinta, pincel, 
e depois quando se aplicou mais ainda na gravura, que, posteriormente, foi deixando de lado. Por que isso aconteceu, por que mudou o meio de trabalho, a pintura com uma linha e a gravura com outra?

R enina - Essa questão é muito interessante e você fez uma pergunta bem curiosa. Já reparou que uma das modalidades de gravura mais adequadas ao expressionismo foi a xilogravura? Ela tem um corte, uma contundência que batia, digamos, com a ideologia do expressionismo. A litografia foi um pouco isso, mas a xilogravura foi mais ainda, principalmente em preto e branco. $\mathrm{H}$ avia um grande contraste e uma certa contundência, do preto versus branco porque no começo a xilogravura era em madeira de fio, em tábua. Para poder trabalhar tinha que se cortar os veios da tábua, que dava uns cortes rígidos, contundentes.

Q uando chegou no século XVIII, um ilustrador. (até como imagem não muito interessante) chamado Thomas Bewick, cortou a árvore de topo, isto é, em fatias. Com isso ele facilitou - ou seja, não havendo nenhuma fibra para ser cortada (porque todas elas estavam de pé) -, mudou o instrumental. Além das facas e das goivas, que são os instrumentos de corte, começou-se a trabal har com o buril, que é um instrumento mais delicado. As so mbras e as luzes poderiam ser trabal hadas de uma maneira mais delicada. Então, a escolha das técnicas depende muito do projeto artístico.

R adhá - C abe aqui lembramos Käthe Kollwitz. Ela tinha de fazer o trabaIho dela daquela forma. $\mathrm{N}$ ão poderia ser de outra maneira.

R enina - Era uma gravadora fantástica na xilo, no metal e na litografia também. Essa escolha da técnica tem muito a ver com isso, com o projeto artístico e claro com o estético.

R adhá - Essa questão apresenta o mesmo ponto que eu havia começado a abordar - esse vir a ser - mas que tem um embasamento romântico. Romântico no bom sentido.

R enina - 0 artista consegue fazer a realização concreta da sua idealização. $N$ esse sentido é que você diz que ele é romântico. Concordo. $Q$ uando se faz um projeto em que se usa tinta nanquim com aguadas, isto é apenas um indicativo. Ao se trabalhar numa gravura em metal, sabe-se exatamente como se vai tratar as zonas em que houve 0 trabal ho com aguadas e com a caneta. $M$ as, se ao fazer, por exemplo, um projeto para litografia, não se usa esse procedimento nem para o projeto. Já se sabe que ali é preciso outro tipo de recurso. I sso é o que se chama de pensamento visual. É saber fazer um repertório em função do seu projeto, porque essa coisa de que o artista espera o "santo baixar" e que ele vai ficar num estado de transe, de inspiração que indica as soluções...Prefiro ficar com G oethe, que dizia que noventa por cento é transpiração mesmo, e o resto é inspiração, para se chegar a um bom termo. Técnica a serviço do imaginário.

\section{As gravuras de uma jovem militante}

R adhá - D e qualquer maneira, você deve convir que há situações que nos 
obrigam a ter uma relação um pouco diferenciada, em função do estado emocional em que o artista se encontra. $N$ ão é pelo fato de ser um artista conhecido, muito convicto de seu trabalho. Por exemplo, toda aquela sua fase no começo, nos anos de 1940 e 1950, muito ligada à questão social, você não podia fazer de outro jeito. $\mathrm{H}$ á também uma correlação da sensibilidade com o material.

R enina - Claro. Você está se referindo àquela fase em que eu fazia xilogravuras. Eu estava na minha juventude militante e aquilo foi de extraordinária importância para mim. É muito interessante, porque hoje, ao analisar aquelas gravuras, vejo que elas não são expressionistas. Certamente porque não têm a contundência típica do expressionismo. Perguntei-me, então, têm o quê? U ma amiga disse-me uma coisa que eu, na hora, fiquei meio espantada. Ela, vendo as gravuras, disse: "engraçado, R enina, você trata todas essas figuras com enorme ternura. R epare nas suas gravuras das mulheres da favela, elas são elegantes, dengosas. Você tem uma relação carinhosa com elas", como que uma atenuante da pobreza.

Fiquei a pensar: vai ver que é por isso que as gravuras não serviam, não é? $\mathrm{N}$ ão serviam para o que eu queria, elas eram incompreendidas. As pessoas que eram militantes gostavam das imagens sofridas, escuras, achavam que aquilo ainda não estava no ponto. Talvez esse fosse um dado que nunca houvesse me ocorrido.

Então, foi isso, depende de sua relação também com tudo. D epende de como se está no mundo, quer dizer, se se está num mundo melhor, pior, não só do ponto de vista emocional, mas até de juízo de valores. As pessoas não têm um código para seguir, afirmando: "agora vou fazer isso". As pessoas mudam, o mundo muda, sua visão de mundo muda, mas a única coisa que permanece é algo que tenho escrito na minha cabeceira. É uma frase de Fernando Pessoa, que diz: "a arte é o aperfeiçoamento sensível da vida, do exterior". A arte está a serviço da melhoria de tudo, do homem por dentro e por fora também. Esse aperfeiçoamento da sensibilidade é um projeto bem aberto. $\mathrm{N}$ ão precisa seguir um código. N os anos de 1950 o mundo era uma coisa, no século XXI é outra. Todos sofremos com o impacto dos acontecimentos. Cada pessoa incorpora e devolve de outra forma.

R adhá - Essa mudança se dá nos anos de 1950?

R enina - Lá pelos anos de 1950, 1960, eu já tinha esgotado esse meu assunto porque percebi que ele poderia ficar viciado, formalista demais. Estava ficando extremamente burilado. Senti que aquilo era um esgarçamento da emoção posta na gravura, e que eu precisava tentar outras coisas.

R adhá - Lembro também que você voltou a pintar, a usar cor outra vez.

R enina - Achei que devia deixar um pouco a gravura em preto e branco e a xilogravura, e deveria, especialmente, tentar outras técnicas que fariam com que eu fosse criando também outros projetos artísticos. Foi difícil essa passagem. No começo achei que eu não iria encontrar o meu prumo. Foram um ou dois anos em que eu fazia somente exercícios. 

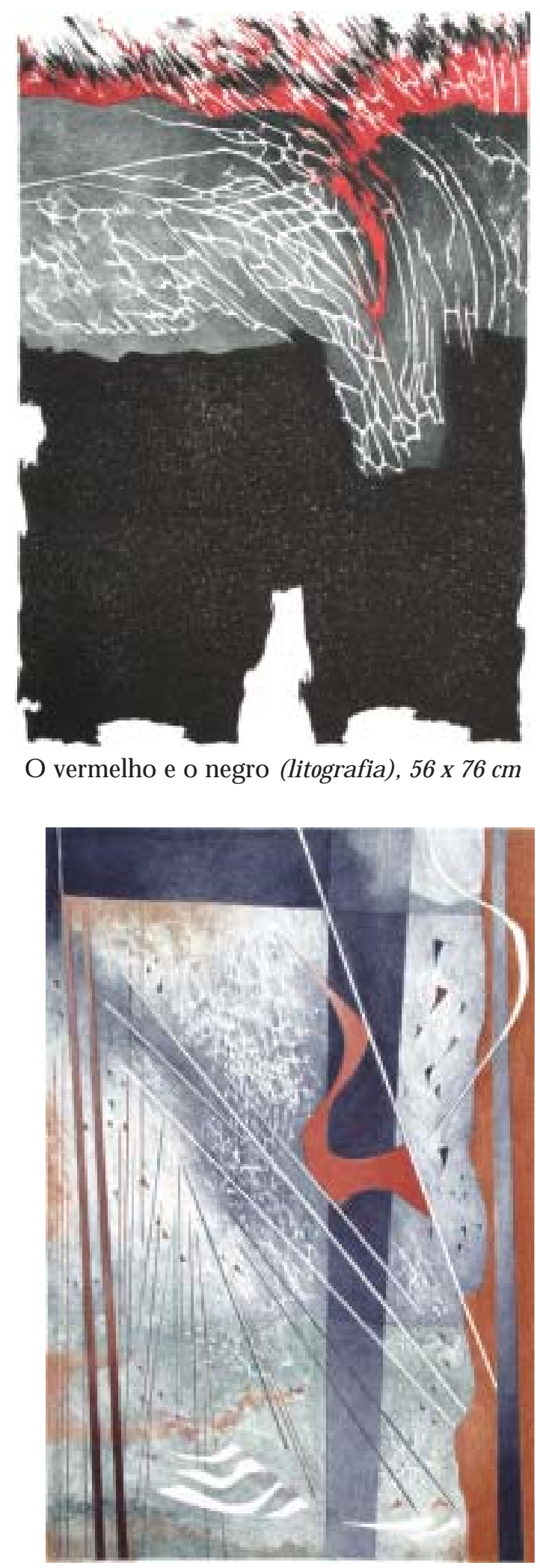

I caro(litografia), $56 \times 76 \mathrm{~cm}$

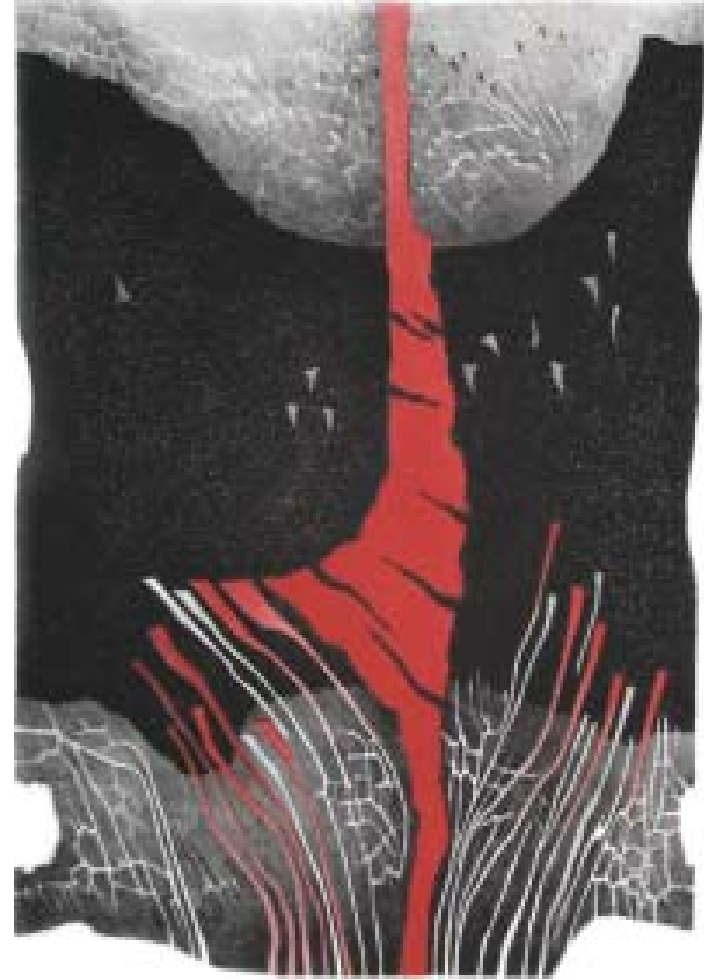

O vermelho e o negro 2 (litografia), 56 × $76 \mathrm{~cm}$

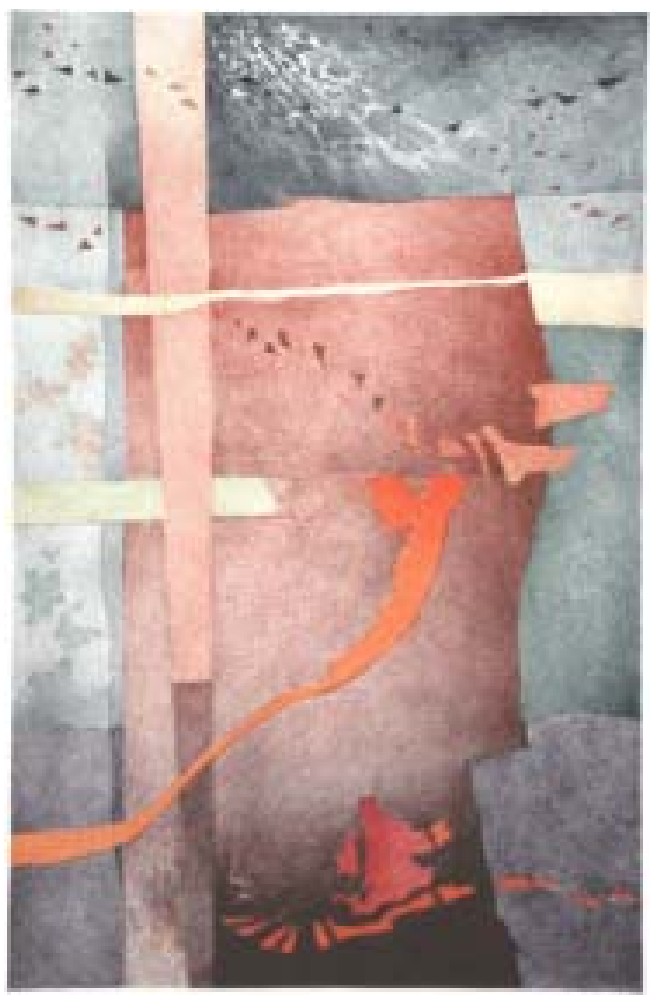

Arroio(litografia), $40 \times 60 \mathrm{~cm}$ 


\section{U ma crítica de Arnaldo Pedroso H orta}

R adhá - M as houve um amigo que muito a ajudou, que disse coisas e tal, e lhe deu uma certa opinião...

Renina - Quem?

R adhá - Arnaldo Pedroso H orta, com um artigo que escreveu sobre você.

R enina - Sem dúvida - o Arnaldo Pedroso $\mathrm{H}$ orta. Ele foi à primeira exposição que fiz depois dos anos de 1950. E ra uma exposição de pintura numa galeria que havia perto do Teatro M unicipal. Ele começou o artigo desaprovando minhas gravuras. Foi muito engraçado, porque ele fez uma análise que me surpreendeu. Ele era um crítico aguçado, mas muito reservado. Eu não sabia que ele olhava com tanta atenção para o meu trabalho. M as decodificou tudo.

Foi como um soco no estômago. Pensei que ele tinha acabado comigo. Q uando li 0 artigo inteiro fiquei tão emocionada que lhe escrevi um bilhete. L embro que foi num balcão de um bar que havia na rua Sete de Abril. D eixei 0 bilhete na portaria do "E stadão". Fiquei realmente espantada porque não podia entender como ele havia conseguido captar o que eu pretendia, porque era a minha primeira exposição em pintura. Ele não só falou do domínio da técnica, mas do universo que eu havia conseguido, como se fosse um renascimento. Afirmava que eu havia saído de alguma coisa que ele considerava como uma cadeia aprisionadora, para algo mais livre.

I sso foi realmente muito estimulante. Até hoje guardo essa crítica com carinho e eu não sabia que tinha um amigo assim. Pois não era crítica de um crítico, mas de um amigo. Esse é o papel do crítico, que deve saber que, num determinado momento, seu papel pode ser decisivo. Compromete-se, coisa que hoje se encontra pouco, pois as pessoas são mais evasivas. $\mathrm{N}$ aquela época o compromisso era grande, o crítico comprometia-se, tanto quanto o artista tinha compromisso com o que apresentava. Espero que isso volte.

\section{A imersão na litografia}

R adhá - D epois dessa fase, que foi muito boa, houve um revival artístico para você. Fez várias exposições e em seguida voltou para a gravura.

R eni na - Voltei para a gravura numa outra dimensão. Como já havia trabalhado intensamente com a pintura, atravessei umas fases que $M$ ário Schenberg chamou de realismo mágico. Em 1970 houve uma exposição de pintura, que preparei com cuidado e que foi elogiada pela crítica. $\mathrm{N}$ ão foi uma exposição grande, tinha apenas vinte e cinco trabalhos. D eu-me uma saudade da gravura, mas eu não queria voltar à xilogravura porque julgava ter encerrado um período. Se bem que uma série de coisas, digamos assim, da escritura da xilogravura, ficaram como repertório.

Resolvi então fazer litografia, porque das técnicas é a mais pictórica. Eu já ensinava litografia no M useu de Arte, onde era professora de gravura, substituin- 
do Poty. M as era tudo em preto e branco, porque não tínhamos muitos recursos. Eu dava aulas, fazia poucas gravuras e desenvolvia meu trabal ho.

Foi quando apareceu uma pessoa visionária que resolveu montar uma gráfica para fazer trabalhos artísticos em litografia, É Isio M ota. D urante a guerra ele foi piloto de provas, tendo sido o único militar que conheço a pedir demissão com uma carta sobre a mesa de um brigadeiro, dizendo: "N ão volto mais aqui". D emitiu-se, com todas as desvantagens, e fundou essa gráfica.

Ele descobriu que havia um impressor, O ctavio Pereira, que trabalhara nos Estados U nidos por muito tempo na "Gemini", e que conhecia bem litografia. É Isio convidou O távio para ser uma espécie de masterprint da gráfica, montada precariamente numa garagem. M uitos artistas o apoiaram, entre as quais $\mathrm{M}$ aria Bonomi e Fayga $\mathrm{O}$ strower. No começo era uma coisa meio precária, mas o negócio foi indo e os artistas foram se interessando. Ela transformou-se, talvez, na única gráfica comercial, porque também vendia o trabalho dos artistas.

Todavia, o mais importante era a qualidade artística excepcional do trabaIho da gráfica, porque ali nunca foram feitas coisas duvidosas. Élsio dava aos artistas todas as oportunidades, dentro do possível e dos recursos. D ava tudo, perguntando a cada um: "quer experimentar, esteja à vontade". A nós, insistia: "pode fazer o que desejar". Ele até começou a importar pedras da Baviera, da região de onde se originou a litografia.

Assim, podíamos fazer gravuras com muitas cores, com até oito impressões. Ele nunca colocou qualquer restrição ao trabalho dos artistas, pois sabia que não poderia condicionar nossa atividade.

$\mathrm{H}$ oje, quem comanda a gráfica é a filha dele, Patrícia que mantém o mesmo espírito. Ela, inclusive, também é pioneira na "digigrafia", nome dado por ela aos trabalhos feitos através da informática, do computador. Já fiz algumas coisas nesse terreno, mas ainda não me adaptei bem aos resultados. Faço al gumas restrições porque também não domino completamente essa técnica. Enfim, não sei até aonde podem ir os recursos e até aonde a própria informática favorece.

$\mathrm{N}$ esse período, que foi de vinte e tantos anos, a litografia foi a técnica a que mais me dediquei. A litografia tem uma coisa aproximativa com um dos processos de que gosto muito: a aquarela e a pintura feita sobre papel. Gosto muito de papel, porque julgo sesr uma matéria bonita, tem uma coisa assim antiga, ancestral, que me fascina, e nunca é inerte. $\mathrm{N}$ a aquarela, o que me fascina é a questão da luz e da transparência, que acho uma maravilha. I sso sempre me interessou, tanto na gravura como na xilogravura. Eu conseguia fazer al gumas coisas nesse sentido, da passagem da sombra para a luz, que já era uma intenção forte no meu trabalho, e a aquarela é perfeita para isso. A litografia conseguia aproximar-me um pouco disso tudo, e eu conseguia trabalhar essas questões da transparência, da luz, da passagem do escuro para o claro. Podem até dizer que essa coisa do claro e do escuro deixa-me um pouco paleolítica. D izem que isso é um problema do Renascimento, mas não é não. 


\section{R adhá - M as viva o Renascimento!}

R enina - Luz e sombra existem até hoje. $N$ ão sei porque deveríamos eliminar essa coisa maravilhosa que é a transparência, a luz e a sombra. Porque se forem consideradas anacrônicas é um outro problema, mas dá-me muito prazer trabalhar com isso. A minha litografia tem essa marca, não é uma litografia pesada, semelhante ao cartaz, para o qual a litografia sempre foi muito adequada. Trabalhei com outro sentido e não fui só eu. Fayga também fez isso. A litografia não tinha aquele sentido da rapidez, da divulgação. Ela é um procedimento que pode ser rápido, como D aumier usou, a própria Käthe Kollwitz também, para ser impresso rapidamente, para ser distribuído, ir para o jornal, porque ela tem essa qualidade. $M$ as peguei a litografia num outro viés. 0 s resultados não foram maus, pelo menos para aquilo que eu pensava.

\section{O aprendizado na E scola de Belas Artes}

D epois de trabalhar vinte e tantos anos com litografia, pensei que deveria retomar um pouco à gravura em metal, que aprendi quando era estudante. Fiz a E scola de Belas Artes graças a meu pai. Ele achava que eu deveria ter um estudo sistematizado, pois do contrário não iria dar certo. Agradeço a ele até hoje e, de fato, esse aprendizado foi muito importante. Porque não era só a questão da artesania que eu deveria aprender. N ão, tive que estudar G eometria D escritiva, Anatomia Artística, Arquitetura A nalítica, $\mathrm{H}$ istória da Arte. Tudo isso, evidentemente, abre horizontes, e foi muito importante. Pode não ser para outras pessoas, mas para mim foi fundamental.

$\mathrm{N}$ a escola tive algumas aproximações, entre as quais, a do meu amigo Poty, que era meu contemporâneo, um maravilhoso gravador em metal. Ele disse quando assistente de $\mathrm{C}$ arlos $\mathrm{O}$ svald - que eu deveria fazer um pouco de gravura em metal. $M$ as argumentou que não sabia se eu iria agüentar, porque não era coisa para mulher. Ele era provocador e eu disse que iria tentar.

$\mathrm{H}$ avia um pequeno ateliê do jornal $\mathrm{O}$ Globo, no centro da cidade, perto da avenida Rio Branco, no Rio de Janeiro. O jornal concordou em colocar ali uma prensa para $\mathrm{C}$ arlos $\mathrm{O}$ svald e Poty. N esse ateliê trabalhavam também três ou quatro alunos, entre eles duas moças. A prensa era pesada e comecei a fazer nela as minhas águas for tes e a imprimir. A prender a imprimir era importante. No momento de imprimir, a prensa tinha que ser rodada por duas pessoas. D epois de uma semana, perguntei ao Poty se não tinha uma prensa menor. Ele respondeu que a prensa era elétrica, mas não havia dado essa informação porque queria saber se eu teria peito para continuar. Então mostrou onde se ligava a prensa. $\mathrm{Q}$ uase bati nele, mas foi um teste, uma brincadeirinha, que ele fez com a gente. $\mathrm{N}$ esse ateliê aprendi muitas coisas. Carlos $\mathrm{O}$ svald era um professor dedicado, tinha paixão pela gravura.

N os anos de 1980 retomei as atividades nessa área. M inha última exposição foi em 2002, só de gravura em metal. Foi importante para mim. M as não sabia 
quando terminaria os preparativos. Eram vinte e tantas peças, somente água forte. Q ueria ver o que conseguiria fazer e resolvi usar água etinta, outra modalidade e que dá uma certa riqueza gráfica.

D eu uma maluquice na minha cabeça, decidi fazer a coisa mais sintética, para ver o que obteria com recursos menores. Se eu usasse três ou quatro modalidades a gravura ficaria mais rica. E ra um desafio que poderia até ser um pouco infantil, porém, achei que era uma boa coisa de se fazer. Acabei fazendo e deu certo porque foi um trabalho muito grande para alcançar esse objetivo, quase obsessivo.

H avia ainda a questão da técnica e perguntava-me se eu conseguiria mesmo. I sto porque no Brasil os artistas sofrem com a precariedade de recursos. 0 papel é importado, tudo a gente inventa. 0 Brasil sobrevive disso. Se não temos uma coisa inventa-se outra.

\section{Os impressores}

O s impressores são exemplos disso. N ão há um único que seja formado em escola técnica. Q uem forma o impressor é o artista. $\mathrm{N}$ isso Élsio teve um papel fundamental. Ele pegava meninos de dezessete e dezoito anos, que hoje têm quarenta e tantos, alguns são até avós. A prenderam na gráfica a fazer impressões, e são maravilhosos. Q uem não conseguia fazer, caía fora. U m impressor facilmente pode destruir uma gravura. A gravura mal impressa é imprestável. Q uer dizer, não se vê o que está na matriz se ela não for bem impressa. Então, o papel do impressor é fundamental. É uma coisa de equipe, ele tem de gostar e entender. Curiosamente, eles percebem as diferenças. Existe uma brincadeira comum nesta gráfica. 0 impressor diz que vai pegar a sua gravura para imprimir com as cores que imprimiu para fulano detal. D igo que vai ficar uma coisa esquisita, mas concordo. Eles sabem qual é o repertório e o rigor de cada artista.

Então, às vezes, digo que o registro não está bom. Ele diz que só eu e ele estamos vendo, eu rebato, e digo que para mim já é o bastante. Se você está vendo e eu também (falo para impressor: "então pronto, vamos corrigir"). Eles (os impressores) fazem de propósito para testar o rigor. Sabem que sou rigorosa. 0 rigor não é inibidor, é uma forma de conduzir o aperfeiçoamento. 0 trabalho de equipe na gráfica tem um tipo de convivência que me atrai. 0 trabal ho de criação é solitário. H á um momento em que esse tipo de convivência é salutar, porque não só você aprende, como ensina. $N$ ão é só a técnica que se ensina. Esses meninos, que hoje são homens, têm um olho fantástico. Eles só têm o curso primário e acabou. M as têm uma certa sensibilidade que é aprimorada.

$\mathbf{R}$ adhá - Sem contar outros dados, todo trabalho técnico que é feito produz na sociedade a possibilidade de ter a obra, de vê-la com mais facilidade. É muito importante o que vocês, gravadores brasileiros, fizeram nas décadas de 1940 a 1950. D eram ao povo a possibilidade de ver e apreciar e até possuir uma obra de arte como essa. 


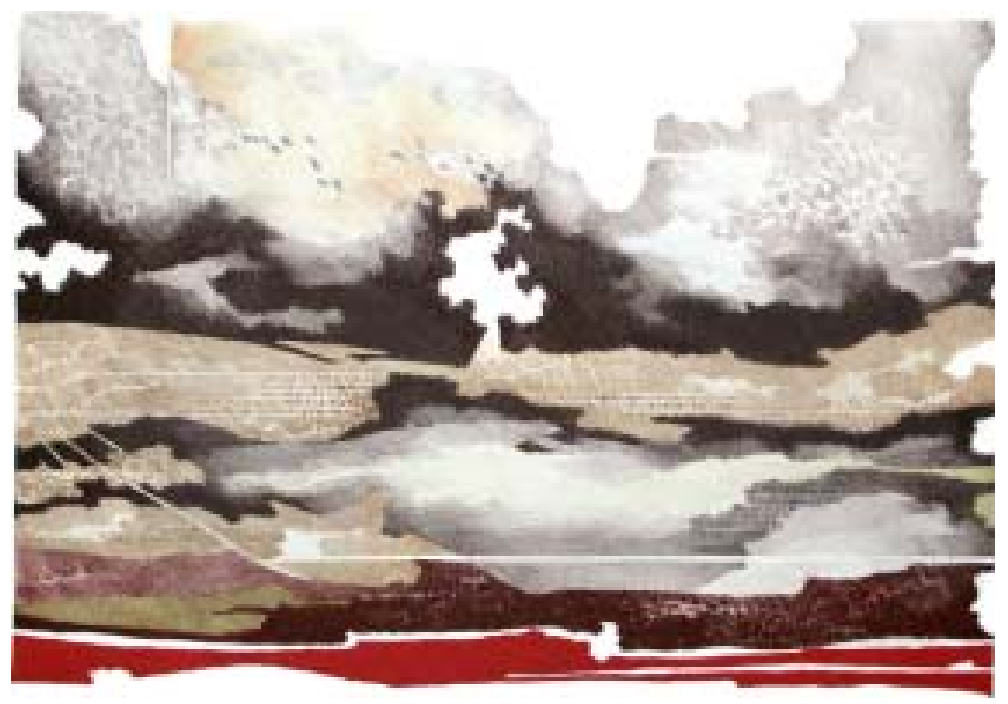

M emória(litografia), 53 x $73 \mathrm{~cm}$

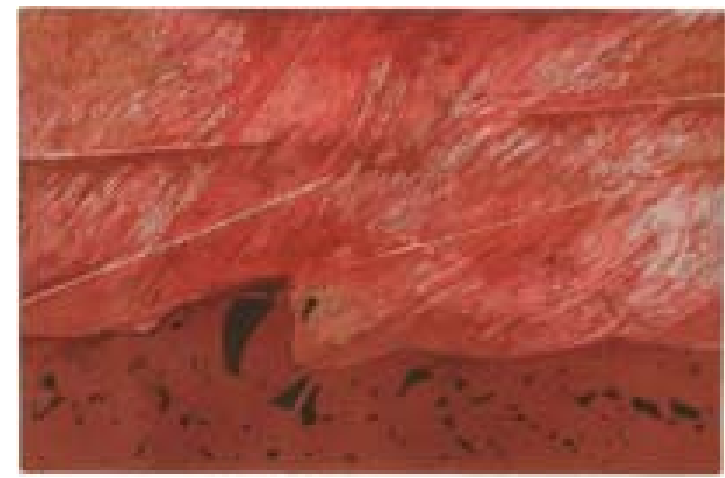

M onólogo(metal), 56 × $76 \mathrm{~cm}$

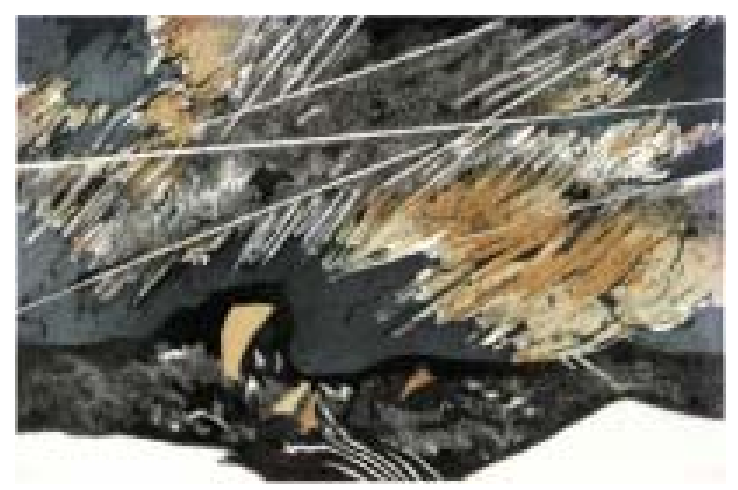

S/ título(metal), 57 x $76 \mathrm{~cm}$

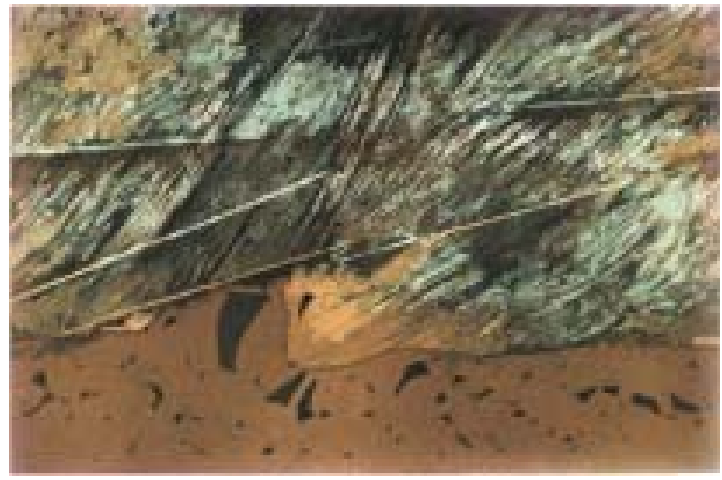

S/ título(metal), $56 \times 76 \mathrm{~cm}$

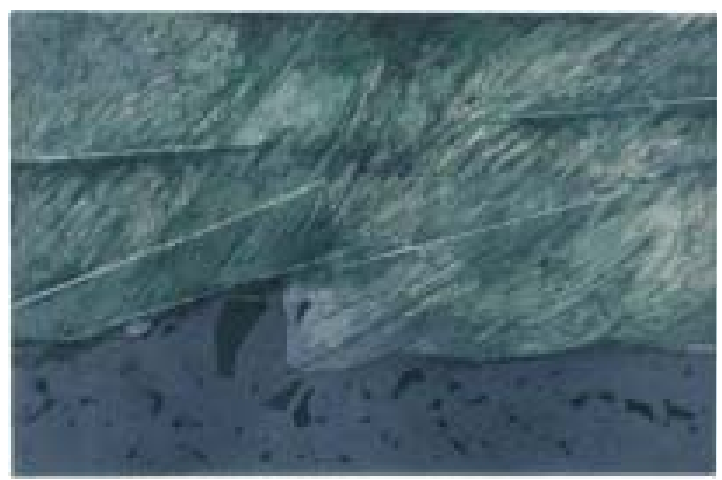

S/ título(metal), $57 \times 76 \mathrm{~cm}$ 


\section{A gravura no Brasil}

R enina - A gravura no Brasil é recente. As de Rugendas não são gravuras, são desenhos executados por litógrafos na Europa, sendo uma documentação narrativa de hábitos e jeitos brasileiros. A verdadeira gravura brasileira nasceu em 1930. Raimundo Cela (1.890-1.954) no Ceará, fazia gravuras ótimas, interessantes, com grande rigor técnico, bem acabadas, ligadas ao seu meio, às jangadas, às rendeiras, aos vaqueiros. D epois aparecem Lívio Abramo, que tem uma importância capital; O sval do G oeldi, com suas notáveis xilogravuras; e al gumas gravuras em ponta seca do Guignard, mas poucas.

A gravura retoma sua força em meados dos anos de 1940, quando Carlos Scliar volta da guerra, vai para o Rio Grande do Sul, e resolve fazer uma coisa importantíssima: fundar o Clube da Gravura, em Bagé. Ele havia convivido com os mexicanos, com o Ateliê de Artes Gráficas, dirigido por Leopold M endez, que tinha a intenção de usar a gravura com esse sentido que você falou, de abertura, de divulgação. Scliar era amigo de $\mathrm{M}$ endez e tomou aquela experiência como um paradigma. Podia ser até regional ismo, mas para salvar algumas visões do Brasil, daquela região, onde ele nasceu, esse clube foi notável. Essa tendência contaminou outros artistas e depois fizemos um pequeno núcleo em São Paulo, com M ário G ruber, L uís Ventura e O távio Araújo. Todavia, não teve a continuidade que havia tido no Rio Grande do Sul.

Essa atividade do Scliar foi básica porque trouxe a idéia de um ateliê. Reuniu um conjunto de artistas em torno de uma idéia, que era fazer registros. A série do Rio Grande do Sul, dos gaúchos, é muito bonita, linda, de uma qualidade incrível. I sso se deve ao Scliar. Ele gravava em linóleo e fazia serigrafias, porque achava que esses procedimentos eram rápidos. E ra o seu jeito.

\section{A geração do R io e L escoschek}

Posteriormente, o M useu de Arte M oderna também criou um ateliê que formou vários artistas, da geração dos anos de 1950, no Rio de J aneiro. H avia também 0 ateliê de Axel Lescoschek. Ele era uma pessoa excepcional, possuía uma técnica incrível, principalmente em xilogravura. Também era um ilustrador maravilhoso e um professor magnífico. Fizemos tudo para mantê-lo no Brasil, mas ele tinha uma lealdade firme para com o seu povo. Afirmava que a Áustria iria precisar dos austríacos saídos do país em virtude do nazismo, para a sua reconstrução. Voltou para lá e foi maltratado, porque era um homem de esquerda. Os austríacos, definitivamente, não são simpáticos às pessoas de esquerda. No fim da vida dele, nós, aqui, fizemos uma espécie de mutirão para ele, porque estava doente e completamente sem recursos. A volta dele, patriótica, para reconstruir a Áustria de nada valeu.

L escoschek nos deu uma lição inesquecível. Ele tinha um enorme respeito pelos alunos, inclusive pelos menos dotados. N unca os desanimava. Afirmava que se 0 aluno estava ali era porque estava procurando alguma coisa. I sso me 
influenciou em minha carreira no magistério, porque o professor não tem o direito de desmantelar o sonho das pessoas. Ele dizia que o papel do professor é dar a cada aluno todos os meios possíveis, inclusive os meios críticos, para que possa se realizar. Se não conseguir, cabe a cada aluno decidir. São poucos os professores que têm esse tipo de cuidado. Por isso foi importante essa minha convivência com Lescoscheck.

R adhá - Essa sua linha de análise da gravura no Brasil está nos convidando a fazer uma exposição com esse objetivo. Poderíamos pensar nisso, porque sua fala vai ao fundo das questões. Você apresenta uma análise global e profunda sobre a gravura, a sua paixão.

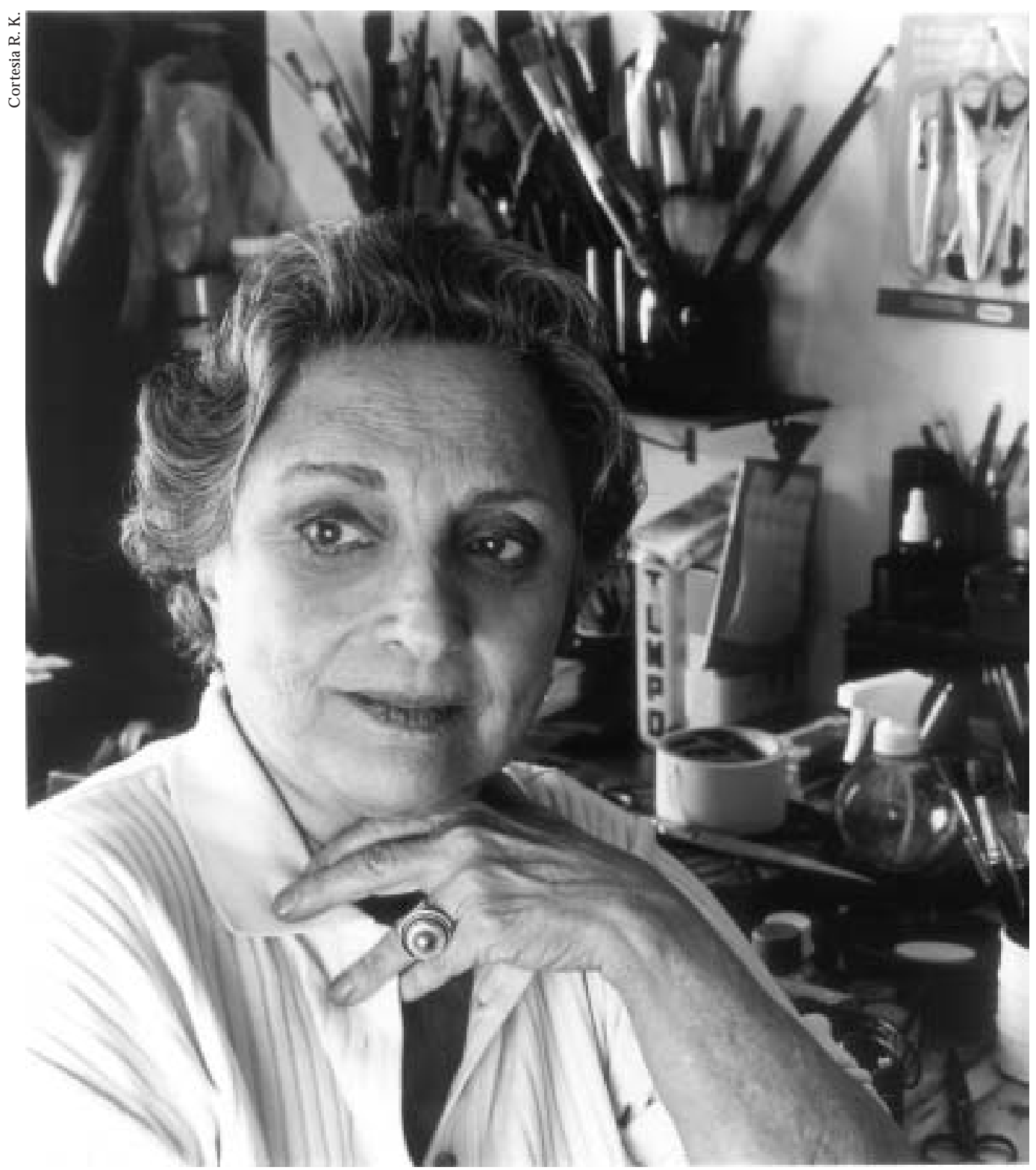

Renina K atz lecionou durante 29 anos na Faculdade de A rquitetura e U rbanismo da U SP. 


\section{Anos dedicados às Artes}

Exposições individuais, entre outras:

1953 - M useu de Arte de São Paulo

1953 - M useu de Arte M oderna de São Paulo

1963 - Petite Galerie - RJ

1973 - Brazilian American Institute - Washington (EU A)

1975 - Galeria Arvil - Cidade do M éxico

1979 - Fundação Gulbenkian - Lisboa

1979 - Galeria Panphill - Roma

1981 - M useu de Arte de São Paulo

1983 - H aia - H olanda

1987 - D ocumenta - Curitiba

1989 - M useu N acional de Belas Artes - Rio-São Paulo

1989 - M useu de Gravura - Curitiba

1992 - Fundação M oreira Salles - Poços de Caldas

1994 - Gravuras em metal - Pinacoteca de São Paulo

1996 - Pinacoteca de São Paulo

1997 - Fundação M aria Vieira da Silva - Lisboa

2001 - M useu de Arte de Santa Catarina

Exposi ções col etivas, entre outras.

III, V, VI, e VII Bienais de São Paulo

1954 - Kunstgeverbenmuseum - Zurich

1954 - M ostra de Arte Brasileira - Varsóvia

1956 - Xylon II M ostra Internacional de xilogravura - Zurich

1956 - XXVII Bienal de Veneza

1974 - Arte Gráfica de H oy - M adri

1974 - Galeria Ziegler - Genebra

1975 - Arte Gráfica Brasileira, nos museus Galiera, Paris; Albertina, Viena; Gulbenkian, Lisboa 1980 - Artistas Brasileiros - Belgrado

1981 - A gravura da mulher brasileira - N ova York

1983 - Brazilian Artists - Barbican Center - Londres

1984 - Tradição e Rutura - Bienal de São Paulo

1985 - Expressionismo e H erança - Bienal de São Paulo

1986 - Bienal de Veneza

1986 - Sala Especial na Bienal de H avana

1987 - Bienal de Lubliana - I uguslávia

1996 - Bienal de Aquarela - M éxico

1998 - Litografia - XI Bienal I bero Americano de Arte - M éxico

1999 - Brasil - Frankfurt / 1999 - Alemanha

2003 - Arte e Sociedade - I taú Cultural - São Paulo

\section{Magistério}

M estre e doutora pela U SP, Renina Katz lecionou durante 29 anos na Faculdade de Arquitetura e U rbanismo da U SP. 


\section{Professora na Faculdade de Arquitetura}

Renina - É paixão mesmo, a gravura é apaixonável e apaixonante. Fui professora na FAU por muitos anos e a ECA nem existia ainda. Os arquitetos manifestaram uma certa resistência a mim, porque não tive formação em arquitetura. Eu dizia que eles eram arrogantes, porque eu fazia parte de uma escola fundada por D. J oão VI, que foi a primeira, e a origem da universidade no Brasil: a E scola de Belas Artes. $O$ que é isso, eu dizia, tenham cuidado comigo, porque tenho ancestralidade.

Fui assistente de Abelardo de Souza, arquiteto, uma pessoa muito aberta. Perguntei-Ihe o que deveria fazer como artista na Faculdade de Arquitetura. Ele disse que não sabia. "Você tem seis meses; você vai ser um gladiador numa arena de trinta leões. D efenda-se. Se não for devorada, será nomeada." Eu retruquei muito bem, vou aprontar-me para isso. M inha primeira providência foi meio cruel. Escolhi um projeto, um programa para eles desenvolverem. Tinha certeza de que não sabiam. Então, iriam depender de mim para desenvolver o projeto. Foi uma molecagem e um artifício de sobrevivência. D epois ficamos amigos e tornei-me parte do corpo docente.

Alguns anos depois, na FAU, estavam outros professores, dois ou três, que não tinham formação de arquitetos, mas a U SP passou a exigir o diploma universitário. Eu era a única que tinha, porque a Escola de B elas Artes do Rio de Janeiro era universidade e eu possuía, também, diploma da Faculdade $\mathrm{N}$ acional de Filosofia, em razão da minha formação didática. Portanto, possuía do is diplomas, era inquestionável. Resultado, fiquei e os outros tiveram de sair. Pensei então em inocular naqueles rapazes algumas idéias interessantes. Aconteceu que na FAU havia ótimos alunos entre eles: Sérgio Ferro, Flávio I mpério, O dileia Setti. U m bando de jovens artistas.

R adhá - Saíram artistas em vez de arquitetos, por sua causa.

R enina - Eles tiveram uma boa formação porque a Faculdade de Arquitetura sempre foi muito aberta. 0 pessoal mais jovem também. Cito alguns: $\mathrm{H}$ élio Vinci, Rubens $M$ atuck, Ferez Khouri, $\mathrm{O}$ diléia Setti. $\mathrm{H}$ avia al gumas disciplinas optativas, nas quais se podia fazer esses exercícios. M inha matéria era do primeiro ano, quando começamos a ensinar os meios e os métodos de representação. Tratava-se da formação da linguagem gráfica do arquiteto, mas havia uma disciplina optativa, somente quem quisesse freqüentava, não era obrigatória. O nde aprenderam a fazer xilografia, a montar coisas na tipografia. $\mathrm{H}$ avia um professor que era muito entusiasmado, Flávio M otta. É um historiador de arte, um pedagogo preocupado com o ensino da arte. Ele mesmo é um artista maravilhoso e dava bastante força ao que eu fazia. Foi ótimo porque isso contaminou vários alunos. $\mathrm{H}$ oje eles são professores na FAU e continuam um pouco com esse procedimento, dando uma certa continuidade. No Brasil as coisas interrompem-se. Q uando se consegue estabelecer uma corrente, realimentada a cada ano, já é um sucesso. 
Penso que cumpri também esse papel de professora, repetindo tudo aquilo que aprendi, não só com Lescoschek, mas com alguns professores excelentes, como Q uirino C ampofiorito e $\mathrm{H}$ enrique $\mathrm{C}$ avaleiro. Eles tinham uma formação acadêmica próxima do impressionismo. M as havia toda uma discussão sobre 0 que era arte, pintura, desenho. A prendi muito com eles, pois houve essa transmissão do conhecimento. 0 que é uma coisa difícil em matéria de arte, porque pode-se passar a parte técnica, emprestar-se um compêndio no qual estejam todas as receitas, mas esta não é a questão decisiva. 0 essencial é transmitir o que fazer com os meios, com o instrumental, ensinando o que resulta daí. Aliada à minha produção artística, juntei essa missão de ser uma divulgadora através do exercício do magistério. 